\title{
LOGO-OD: THE APPLICABILITY OF LOGOTHERAPY AS AN ORGANISATION DEVELOPMENT INTERVENTION
}

\author{
DANIEL H BURGER \\ FREDDIE CROUS \\ GERT ROODT \\ Department of Human Resource Management \\ University of Johannesburg \\ South Africa \\ Correspondence to: Daniel H Burger \\ e-mail: dburger@resolve.co.za
}

\begin{abstract}
The study investigated the relationship between "resistance to or readiness for change" (ROR-change) and "meaning seeking", and whether a logotherapy-based intervention - Logo-OD - would impact on resistance to change. A quasi-experimental design and various statistical procedures were applied to test formulated hypotheses. Of a survey population of 1637 individuals, 193 and 76 respondents formed part of the pre- and post-test samples respectively. Whereas a significant relationship was established between said constructs, no significant effect of Logo-OD was observed. These results supported the primary conclusions emanating from the literature: the role of Logo-OD is one of a positive trigger event for organisational change.
\end{abstract}

Keywords: Organisational change, resistance to change, organisation development (OD), Viktor Frankl, logotherapy

Whereas a prominent focus in both classic and contemporary literature is on the utilisation of the organisation's human resources (HR) as a competitive advantage (see Barney, 1995; Cascio, 1998; Cook \& Crossman, 2004; Drucker, 2002; Gratton, 2000; McGregor, 1960; O'Reilly \& Pfeffer, 2000; Prahalad \& Hamel, 1990; Richardson \& Vanderberg, 2005; Schuler \& Jackson, 1999; Schuler, Jackson \& Storey, 2001), the need for organisations to adapt to increasingly turbulent changes has enjoyed similar attention (see Burnes, 2003, 2004; Carnall, 2003; Cascio, 1995; Chapman, 2002; Counsell, Tennant \& Neailey, 2005; Hacker \& Washington, 2004; Higgs, 2003; Johnson, 2004; Weber \& Weber, 2001; Xavier, 2005). These two factors together constitute one of the greatest challenges faced by the modern organisation, namely that "human capital is fundamentally different from financial and technological capital" (Gratton, 1998, p. 13), as the realisation of human potential is dependent upon employees' co-operation (Jackson \& Schuler, 1999). However, organisational change "has left this resource severely wounded and the people themselves increasingly disenfranchised" (Morin, 1994, p. 53), therefore threatening the very same employee commitment required to secure a competitive advantage. Subsequently, people constitute both "an essential factor" and "the biggest obstacles" to successful change (Smith, 2005a, p. 408, 2005b, p. 152). It is argued in this article that a central construct in determining individuals' attitudes towards organisational change - albeit resistance to or readiness for change - is the meaning that they find in the organisational context.

\section{Organisational change \\ The context of organisational change}

Organisational change is defined as the significant alteration of any number of elements in the organisation, including behaviour, structures, technology, processes and/or strategy. A central theme found throughout these various foci of organisational change is the potential impact on and the importance of employee behaviour (Elving, 2005; Ghoshal \& Bartlett, 1996; Porras \& Robertson, 1992).

Since organisations are viewed as open systems (Jackson \& Schuler, 1999; Robbins, 1990; Schein, 1994), the need for change may originate from both their external and internal environments (Mullins, 1999). Organisations generally respond to catalysts for change through either first- or second-order changes (Carbery \& Garavan, 2005; Cummings \& Worley, 2001). Examples of large-scale organisational changes include downsizing (Fiorito, Bozeman, Young \& Meurs, 2007; Hellgren, Näswall \& Sverker, 2005; McGreevy, 2003a), restructuring (Ambrose, 1996; Carbery \& Garavan, 2005; Watson, 2003), business process re-engineering (Hammer, 1996; Hammer \& Champy, 1993) and mergers and acquisitions (M\&As) (Cartwright \& Cooper, 1994, 1995).

Organisational change initiatives often have severe implications for employees. These include stress (Vakola \& Nikolaou, 2005; Vakola, Tsaousis \& Nikolaou, 2004), work overload (Higgs, 2003; Ugboro, 2006), career plateaus and obsolescence (Greenhaus, Callanan \& Godshalk, 2000), the survivor syndrome (Bashford, 2004; Doherty \& Horsted, 1995), the new psychological contract (McGreevy, 2003b; Watson, 2003) and job insecurity (De Cuyper \& De Witte, 2005). It comes as no surprise then that people-related issues constitute the primary reason for the failure of change efforts (Atkinson, 2005; Chawla \& Kelloway, 2004; Karp, 2004; Vakola et al., 2004; Worrall \& Cooper, 2004). In this context, resistance to change has been shown to play a prominent role (see Bovey \& Hede, 2001; Chawla \& Kelloway, 2004; Vakola et al., 2004).

Resistance to change and readiness for change

Resistance to change involves employee attitudes that manifest in behaviours (such as reduced output, strikes, sabotage and absenteeism) (Chawla \& Kelloway, 2004; Lawrence, 1970; Nguyen-Huy, 2000; Wanberg \& Banas, 2000; Young, 2000) aimed to "discredit, delay or prevent" change implementation (Newstrom \& Davis, 1997, p. 403). This occurs both on lower and managerial levels in the organisation (Folger \& Skarlicki, 1999; Young, 2000). A prominent cause of resistance to change is the threat of losing something meaning $\mathrm{ful}^{1}$ to the employee, such as the loss of security and stability (Chreim, 2006; Ugboro, 2006), status (Proctor \& Doukakis, 2003), competence or self- 
efficacy (Chreim, 2006), and the vision and values of the status quo (Trader-Leigh, 2002).

Readiness for change constitutes the attitudinal opposite of resistance to change (Bovey \& Hede, 2001; Elving, 2005; Piderit, 2000). This construct involves "organizational members' beliefs, attitudes and intentions regarding the extent to which changes are needed and the organization's capacity to successfully make those changes" (Armenakis, Harris \& Mossholder, 1993, pp. 282-283), and is considered a critical factor in ensuring that change initiatives are successful (Chapman, 2002; Chawla \& Kelloway, 2004; Smith, 2005a, 2005b; Weber \& Weber, 2001).

\section{Organisation development}

The discussion above suggests that facilitating organisational change is dependent on changing employee attitudes from resistance to change to readiness for change. The role of organisation development (OD) herein lies in contributing to employees viewing change as "an opportunity rather than a threat" (French \& Bell, 1999, p. 2). Although OD is defined in a number of ways in the literature, five central themes emerge: it is based on behavioural scientific knowledge and humanistic values, and is aimed at implementing planned change in various organisational subsystems towards reaching organisational goals and improving organisational effectiveness (see Beckhard, 1994; Cummings \& Worley, 2001; French \& Bell, 1999). The humanistic basis of OD constitutes the primary factor that distinguishes it from other change approaches (De Greene, 1982).

Although OD may impact on various organisational subsystems, "the human-social subsystem is the initial change target" of interventions (French \& Bell, 1990, p. 54). To facilitate planned change in this subsystem, then, a number of approaches and interventions have been developed, some of which include sensitivity training (Argyris, 1964; Robbins, Odendaal \& Roodt, 2003; Shimmin \& Van Strien, 1998), Gestalt-OD (French \& Bell, 1999), process consultation (Schein, 1994, 1995) and appreciative inquiry (AI) (Berrisford, 2005; Ludema, Cooperrider \& Barrett 2001; Watkins \& Mohr, 2001). Despite the value inherent in these approaches, it may be argued that their respective foci do not adequately address employees' search for meaning, which, given the centrality of meaning assumed in the success of organisational change, signals the need for the development of a novel OD intervention encompassing such a focus.

\section{Logotherapy}

The potential value of Logo-OD cannot be suitably conceptualised without a discussion of the principles that form the foundation of this approach. Logotherapy was developed by Viktor Frankl, an Austrian psychiatrist/neurologist and Holocaust survivor. His most famous work, Man's Search for Meaning, in which he both conveyed his experiences in the Nazi concentration camps and provided an overview of his 'Third Viennese School of Psychotherapy'2 (Frankl, 2000b), has sold more than nine million copies in 23 languages (Havenga \& Coetzer, 1997; Washburn, 1998).

A central tenet of logotherapy is that meaning plays a crucial role in one's life (Frankl, 1984). The discovery of meaning will significantly improve one's quality of life (Greenstein \& Breitbart, 2000), irrespective of the circumstances. Logotherapy, which denotes 'therapy through meaning', is aimed at helping one find such meaning, or purpose, in life (Fabry, 1987, 1988; Frankl, 1967, 1984, 1986, 1988, 1990, 1992, 2000a, 2000b).

Frankl proposes that all human beings have freedom of will; that finding meaning is one's central motivating force in life (known as the will to meaning'), and that the meaning of life is not created, but found through experiential, creative and attitudinal values (Frankl, 1967, 1978, 1984; Kausch \& Amer, 2007; Moomal, 1999; Southwick, Gilmartin, McDonough \& Morrissey, 2006). Failure to find meaning results in existential frustration and the existential vacuum (Frankl, 1988). In addition to the role of the 'tragic triad' of suffering, guilt and an awareness of the transitoriness of human existence (Frankl 1984, 2000a), Frankl attributes these existential conditions to the "crumbling" of "traditional cornerstones" such as the family, church, school and state (Fabry, 1987, p. 96) and the variety of value orientations in contemporary societies (Das, 1998), both of which constrain the finding of meaning. Symptoms of these states include boredom, apathy (Das, 1998; Frankl, 1984) and various psychopathologies (Moomal, 1999). If prolonged, this may result in 'noögenic neurosis' - a frustration of the fundamental human need for meaning in life (Das, 1998; Shantall, 1989). As the causes of noögenic neurosis are not psychological, psychotherapy will not be effective in addressing this condition. Rather, logotherapy is to be applied when a person is "caught in the existential despair over the apparent meaninglessness of his life" (Frankl, 1969, p. 99).

\section{Logo-OD: The applicability of logotherapy as an OD intervention}

The importance of meaning in and for the contemporary organisation As the role of institutions to which individuals have traditionally turned for direction in finding meaning in their lives has weakened over the past few decades, individuals have begun attaching increased importance to their work and organisations to define their own purpose in life (see Bartlett \& Ghoshal, 1994; Heil, Bennis \& Stephens, 2000; Morin, 1995). Authors such as Frances (1995), Kets de Vries (2001), McGreevy (2003b), Pratt and Ashforth (2003), and Rossouw (2002) argue that the role of work goes beyond providing one with a paycheque to encapsulate aspects such as personal development, identity, self-esteem, and ultimately, meaning. These propositions largely reflect Frankl's $(1984,1990)$ research on the impact of unemployment on the experience of meaning.

Assisting individuals in finding meaning should not be interpreted as organisational altruism -it makes business sense: research "has shown that a sense of meaning is an important correlate of work motivation and positive work attitudes" (Schlecter \& Engelbrecht, 2006, p. 4). Meaning is also related to organisational commitment (Markow \& Klenke, 2005), which, in turn, relates to change readiness (Bennett \& Durkin, 2000; Nijhof, De Jong \& Beukhof, 1998). Moreover, individuals are more likely to change if the organisation relates the need for change to "something they care about in the form of a deeper meaning or a higher purpose" (Karp, 2004, p. 353).

\section{Logo-OD as a positive trigger event for organisational change}

Whereas change is a necessary and inevitable condition to which many organisations must adapt if they are to remain competitive in the market, initiatives undertaken to bring about such change often have detrimental consequences for employees - one of which is a threat to the meaning individuals experience in their lives. As a result, employees may display resistance to change, which constitutes a significant constraint to the success of change efforts.

The application of logotherapy in this context may therefore have a role to play in reducing employees' resistance by assisting them in their search for meaning amid organisational change; an application which, due to this foreseen role in facilitating change implementation, will constitute an OD intervention. On a conceptual level, this argument may be further supported by emphasising the behavioural-scientific basis of logotherapy 


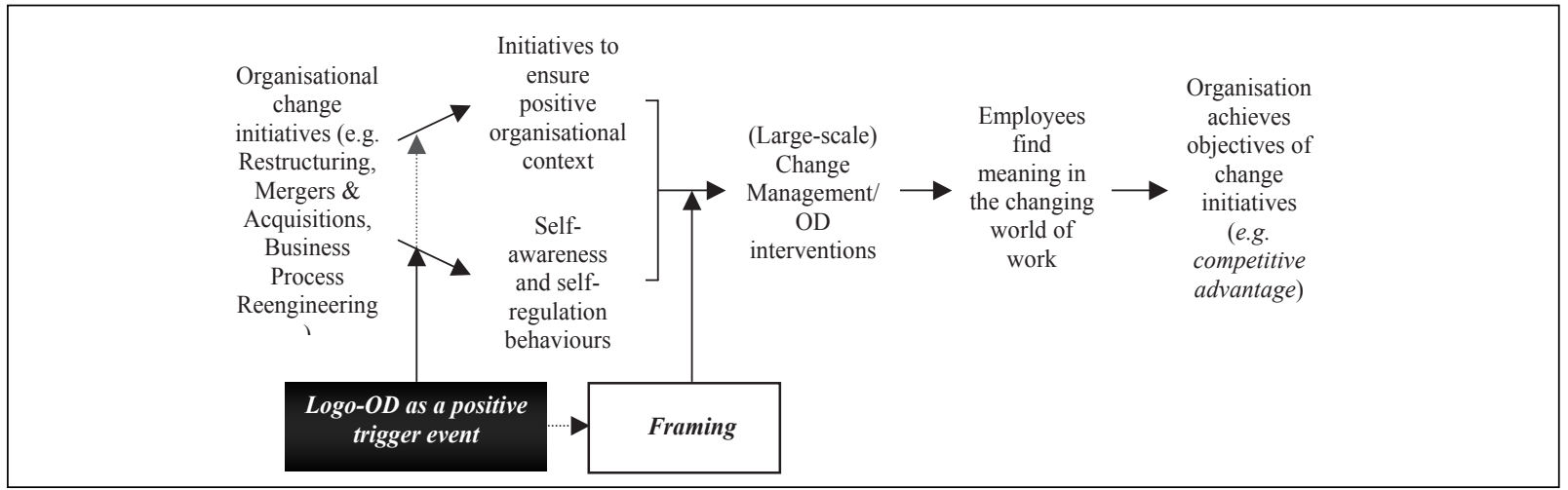

FIGURE 1

Logo-OD as a positive trigger event to facilitate organisational change

as a recognised model of psychology, the overlap between logotherapeutic and humanistic values, and the focus of Logo-OD on the human-social subsystem in bringing about planned change - all of which were shown earlier to represent fundamental characteristics of OD.

However, given the complex nature of organisational change and employee responses thereto, the isolated application of Logo-OD is unlikely to bring about a sufficient shift in employee attitudes to ensure readiness for change. Rather, the proposed role of Logo-OD in this context is one of a positive trigger event in facilitating organisational change.

Avolio and Luthans (2006) and Luthans and Avolio (2003) argue that a trigger event refers to a critical incident that causes individuals to realise that their behaviour must change if they are to address a specific situation or achieve a desired outcome. Such trigger events may be planned or unplanned, as well as be negative or positive. Whereas these authors focus on the role of such trigger events in Authentic Leadership Development (ALD), it may be argued that this concept is also applicable to the aim of this study. In particular, parallels can be drawn between the concept of an authentic leader and what Frankl would denote as an individual who has found meaning in his or her life. What is more, the model for developing ALD, presented by Avolio and Luthans (2006) and Luthans and Avolio (2003), can be amended to indicate how the concepts outlined may play a critical role in bringing about readiness for change by focusing on employees' search for meaning in the organisational context. This amended model is presented in Figure 1

In addition to the need for a "myriad of follow-up interventions" (Avolio \& Luthans, in Puente, Crous \& Venter, 2007, p. 17), Figure 1 indicates that achieving sustainable change also requires a positive organisational context and the appropriate framing of organisational change initiatives. Whereas these concepts are further explored in the Discussion section, it was the role of a planned positive trigger event - in the form of Logo-OD - in facilitating organisational change that formed the foundation of this study. Subsequently, the empirical investigation conducted encapsulated three hypotheses:

- Hypothesis 1: A logotherapeutic intervention will result in statistically significant differences between pre- and post-test measures on the resistance-readiness dimension (ROR-change)

- Hypothesis 2: The ROR-change measures of a group that receives a logotherapeutic intervention will differ significantly from the measures of a group that does not receive an intervention

Lewin's (1951) classic change model implies that for an OD intervention to be successful in facilitating change, it must reduce change-restraining forces, and increase change-driving forces. Therefore, should Logo-OD be effective in reducing resistance to change and enhancing readiness for change - as tested by hypotheses 1 and 2 - it can be concluded that this approach has a direct impact on the effectiveness of change facilitation.

- Hypothesis 3: The meaning and biographical profiles of individuals closer to the resistance pole will differ significantly from the profiles of those closer to the readiness pole

This study proposes a relationship between the experience of meaning and the display of ROR-change. In addition, research has shown that demographic factors may play a substantial role in finding meaning in work (see Caudron, 1997; Mirvis, 1990). Subsequently, hypothesis 3 was aimed at establishing whether employees' likelihood of displaying ROR-change could be predicted based on i) their profiles on an instrument that measures meaning in life and ii) their demographic characteristics.

\section{Purpose of the study}

The first objective of this study was to investigate the relationship between the constructs of ROR-change and meaning. Secondly, although the role of Logo-OD is proposed to be one of a positive trigger event for organisational change, the magnitude of its effect was explored by investigating its direct impact on the ROR-change dimension.

\section{RESEARCH DESIGN}

\section{Research approach}

This study was conducted within the empirical-analytical or positivistic paradigm (Huysamen, 1993). A cross-sectional survey design was utilised to describe the population at the time of the study (Kerlinger \& Lee, 2000). Given the purpose and limitations of the study, a "patched up" quasi-experimental design (Campbell \& Stanley, 1963, p. 57) encompassing pre- and post-tests, as well as experimental and control groups, was applied.

\section{Research methodology}

The research context

The target population was a South African (SA) organisation in the information and communication technology (ICT) industry - an environment characterised by constant change. For example, in addition to its strategy of continuous acquisitions, the organisation also launched the implementation of an enterprise resource planning system throughout a number of its divisions shortly before this research was undertaken. 
TABLE 1

Respondents' Biographical Details

\begin{tabular}{|c|c|c|c|c|c|c|c|}
\hline \multirow[b]{3}{*}{ DEMOGRAPHIC } & \multirow[b]{3}{*}{ CATEGORY } & \multirow{2}{*}{\multicolumn{2}{|c|}{$\begin{array}{l}\text { PRE-TEST } \\
(n=193)\end{array}$}} & \multicolumn{4}{|c|}{ POST-TEST CONDITIONS } \\
\hline & & & & \multicolumn{2}{|c|}{$\begin{array}{l}\text { EXPERIMENTAL } \\
(n=32)\end{array}$} & \multicolumn{2}{|c|}{$\begin{array}{l}\text { CONTROL } \\
(n=46)\end{array}$} \\
\hline & & $\mathbf{n}$ & $\%$ & $\mathbf{n}$ & $\%$ & $\mathrm{n}$ & $\%$ \\
\hline \multirow{2}{*}{ Gender } & Male & 105 & $54.4 \%$ & 18 & $56.25 \%$ & 22 & $47.83 \%$ \\
\hline & Female & 88 & $45.6 \%$ & 14 & $43.75 \%$ & 24 & $52.17 \%$ \\
\hline \multirow{4}{*}{ Race } & African & 18 & $9.3 \%$ & 1 & $3.13 \%$ & 1 & $2.17 \%$ \\
\hline & Coloured & 8 & $4.1 \%$ & 1 & $3.13 \%$ & 2 & $4.35 \%$ \\
\hline & Indian & 10 & $5.2 \%$ & 1 & $3.13 \%$ & 2 & $4.35 \%$ \\
\hline & White & 157 & $81.3 \%$ & 29 & $90.63 \%$ & 41 & $89.13 \%$ \\
\hline \multirow{6}{*}{ Length of service } & Less than 1 year & 28 & $14.5 \%$ & 3 & $9.38 \%$ & 8 & $17.39 \%$ \\
\hline & $1-2$ years & 30 & $15.5 \%$ & 3 & $9.38 \%$ & 5 & $10.87 \%$ \\
\hline & $2-4$ years & 15 & $7.8 \%$ & 1 & $3.13 \%$ & 6 & $13.04 \%$ \\
\hline & $4-5$ years & 11 & $5.7 \%$ & 3 & $9.38 \%$ & 1 & $2.17 \%$ \\
\hline & $5-7$ years & 23 & $11.9 \%$ & 5 & $15.63 \%$ & 5 & $10.87 \%$ \\
\hline & More than 7 years & 84 & $43.5 \%$ & 17 & $53.13 \%$ & 21 & $45.65 \%$ \\
\hline \multirow{6}{*}{ Age } & $18-25$ & 15 & $7.8 \%$ & 1 & $3.13 \%$ & 2 & $4.35 \%$ \\
\hline & $26-30$ & 21 & $10.9 \%$ & 3 & $9.38 \%$ & 4 & $8.70 \%$ \\
\hline & $31-40$ & 57 & $29.5 \%$ & 5 & $15.63 \%$ & 19 & $41.30 \%$ \\
\hline & $41-50$ & 66 & $34.2 \%$ & 15 & $46.88 \%$ & 17 & $36.96 \%$ \\
\hline & $51-60$ & 28 & $14.5 \%$ & 8 & $25.00 \%$ & 3 & $6.52 \%$ \\
\hline & Older than 60 & 4 & $2.1 \%$ & 0 & $0.00 \%$ & 1 & $2.17 \%$ \\
\hline \multirow{5}{*}{ Level of education } & Lower than Grade 12 & 9 & $4.7 \%$ & 2 & $6.25 \%$ & 3 & $6.52 \%$ \\
\hline & Grade 12 & 45 & $23.3 \%$ & 4 & $12.50 \%$ & 12 & $26.09 \%$ \\
\hline & Grade 12 \& diploma/certificate & 62 & $32.1 \%$ & 11 & $34.38 \%$ & 15 & $32.61 \%$ \\
\hline & Undergraduate degree & 30 & $15.5 \%$ & 6 & $18.75 \%$ & 7 & $15.22 \%$ \\
\hline & Postgraduate degree & 45 & $23.3 \%$ & 9 & $28.13 \%$ & 9 & $19.57 \%$ \\
\hline \multirow{5}{*}{ Level in organisation } & Staff & 84 & $43.5 \%$ & 10 & $31.25 \%$ & 22 & $47.83 \%$ \\
\hline & Supervisory management & 12 & $6.2 \%$ & 3 & $9.38 \%$ & 1 & $2.17 \%$ \\
\hline & Junior management & 40 & $20.7 \%$ & 7 & $21.88 \%$ & 11 & $23.91 \%$ \\
\hline & Middle management & 29 & $15.0 \%$ & 6 & $18.75 \%$ & 8 & $17.39 \%$ \\
\hline & Senior management/executive & 23 & $11.9 \%$ & 6 & $18.75 \%$ & 3 & $6.52 \%$ \\
\hline
\end{tabular}

NB: Participants who failed to specify their demographic characteristics were omitted from this table, which accounts for percentages not aggregating to $100 \%$ in some instances.

\section{Participants}

The pre-test sample consisted of 193 individuals and formed part of a target population of approximately 4812 and a sampling frame of 1637 individuals. The post-test sample, in turn, was categorised into two groups, namely the experimental group, which consisted of 32 participants, and the control group, which consisted of 46 employees. The key findings, as pertaining to the descriptive statistics of this study, are reported in Table 1.

The percentages provided in the table above both depict the composition of the pre- and post-test samples, and facilitate the reaching of a number of conclusions. Firstly, neither the pre- nor the post-test samples reflected the demographics of the sample frame in terms of race, gender or length of service (information regarding the target population was only available in terms of these three biographical variables), which constrained the external validity of the study. This is apparent from a comparison between the data in Tables 1 and 2 (see below), the latter of which provides a summary of the demographics of the population and the sampling frame. Secondly, the equivalence of the control and experimental groups may be disputed with

TABLE 2

Comparison of the target population and sample in terms of race and gender

\begin{tabular}{llll}
\hline DEMOGRAPHIC & TARGET POPULATION & SAMPLE & DISCREPANCY \\
\hline Black males & $21 \%$ & $16 \%$ & $5 \%$ \\
Black females & $12 \%$ & $12 \%$ & $0 \%$ \\
White males & $46 \%$ & $45 \%$ & $1 \%$ \\
White females & $21 \%$ & $23 \%$ & $2 \%$ \\
Incomplete information & $0 \%$ & $4 \%$ & \\
\hline Total & $100 \%$ & $100 \%$ & \\
\hline
\end{tabular}

regard to a number of the demographic factors, therefore also potentially impacting on the interpretation of the findings.

Differences are also apparent in the composition of the preand post-test samples. Although at least some of this may be attributed to attrition, the potential impact of selection effects cannot be negated. Whereas Rosnow and Rosenthal (1996) refer to this issue as volunteer bias, an alternative explanation may be found within the literature presented in this study. Frank maintains that the 'call for meaning' is sometimes not heard by all individuals (Shantall, personal communication, 3 December 2006). It may then be suggested that one's demographic characteristics may impact on one's meaning-seeking behaviours, for example, whether one would attend a workshop aimed at addressing meaning in the organisational context.

\section{Measuring instruments}

The ROR-change dimension was operationalised by means of the Change Readiness Inventory (CRI), initially developed by Kinnear and Roodt (1998) as the Organisational Inertia Survey. The CRI consists of 109 items grouped into 12 categories according to the Burke-Litwin model (Roodt, Kinnear \& Erwee, 2003 , p. 3). These categories, in turn, are grouped into two groups of variables, namely transformational (external environment, leadership, mission and strategy, and organisational culture supportive of change) and transactional (structure, systems, change management practices, work-unit climate, motivation, job/task requirements, individual needs and values, and individual and organisational performance) variables.

A high score on the CRI serves as an indication that one is likely to display readiness for change, whereas a low score suggests 


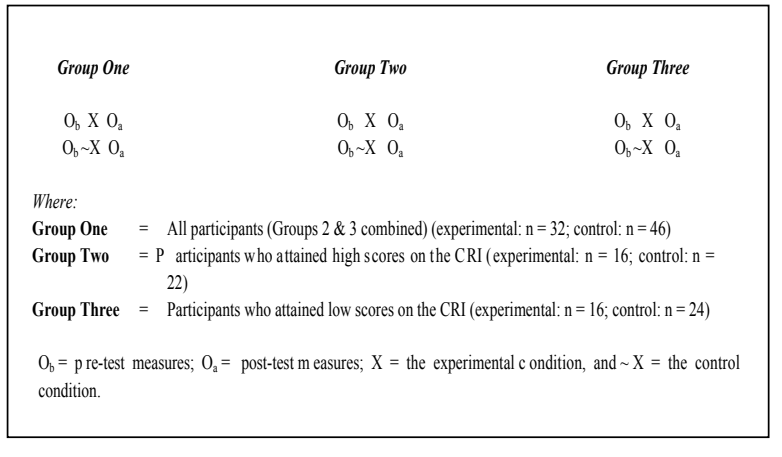

FIGURE 2
Data paradigm for statistical analysis

that the individual may be resistant to change. Applications of this instrument in both the SA and Australian contexts yielded satisfactory validity (two secondary factors extracted in the SA application, and one extracted in Australia) and reliability (Cronbach's alpha coefficients of 0.981 and 0.887 for secondary factors in the SA standardisation and 0.988 in the Australian context) (see Kinnear \& Roodt, 1998; Roodt, Kinnear, Erwee, Smith, Lynch \& Millet, 2001). From this, the rationale for the use of the CRI for the proposed research is apparent.

Frankl's concept of meaning was operationalised by means of the Personal Meaning Profile (PMP) developed by Wong (1997, 1998). The PMP, which measures the 'integrative construct' of meaning seeking (Wong, 1997) is a self-report measure consisting of 57 items based on seven dimensions: religion, achievement, relationship, intimacy, self-transcendence, selfacceptance, and fair treatment. Higher scores on the PMP suggest that one is approximating "the ideally meaningful life" (Wong, 1997, p. 4).

Wong (1998) provides a comprehensive overview of the standardisation of the PMP, which includes indications of the construct validity, predictive validity and reliability of this instrument. Studies indicate that primary factors extracted explained up to $67 \%$ of the variance observed, therefore pointing to the construct validity of the instrument. Wong (1998) further reports a three-week test-retest reliability of $r=0.85$ and a Cronbach's alpha coefficient of 0.93 for the total PMP. This, together with the sound theoretical basis of this instrument, informed the decision to apply the PMP in this study.

\section{Research procedure}

The first step in the research involved administering the CRI and PMP to the sampling frame. Based on the distribution of the 193 respondents' CRI scores, three groups were formed: whereas Group 2 consisted only of individuals who scored high on the CRI (high change readiness), Group 3 included only participants who had low CRI scores (high change resistance) ${ }^{3}$. Group 1 included all participants (i.e. Groups 2 and 3 combined). Participants were subsequently randomly assigned to the experimental and control conditions. Only the experimental group attended the Logo-OD intervention. Twenty-six of the twenty-eight individuals ${ }^{4}$ who declined to attend were replaced beforehand by means of matching (Rosnow \& Rosenthal, 1996) on the basis of primarily their pre-test CRI scores ${ }^{5}$. Upon completion of the intervention, the CRI and PMP were again administered to all participants.

\section{Statistical analysis}

All results were analysed by the Statistical Consultation Service of the University of Johannesburg. These analyses were directed by the data paradigm represented in Figure 2.

\section{RESULTS $^{6}$}

\section{Factor and reliability analysis}

As the size of the sample precluded the use of conventional approaches to factor analysis, an adapted approach was utilised. This involved treating the theoretical dimensions of both the CRI and PMP as first-order factors, upon which second-order factor analyses were conducted.

Reliability analyses of the 12 CRI factors indicated Cronbach alpha coefficients ranging between 0.733 and 0.947 in the pretest, and 0.728 and 0.939 in the post-test. The Principal Axis Factoring method was applied in extracting second-order factors from the 12 CRI dimensions. Rotation was conducted according to the Varimax method with Kaiser Normalisation. Two second-order factors were identified in the pre-test factor analysis, which were collapsed into one to allow for comparison with the single second-order factor extracted from the posttest data. Whereas the collapsed pre-test second-order factor (Cronbach alpha $=0.98$ ) explained $65.064 \%$ of the variance extracted, $63.232 \%$ of the variance was explained by the secondorder factor extracted in the analysis of the post-test data (Cronbach alpha $=0.982$ ). Factor loadings ranged between 0.617 and 0.918 on the pre-test, and 0.659 and 0.918 on the post-test.

Following the reliability analyses of the seven PMP factors, Cronbach alpha coefficients ranging between $0.616^{7}$ and 0.908 in the pre-test, and 0.686 and 0.902 in the post-test were found. A second-order factor analysis according to the Principal Axis Factoring method yielded one second-order factor in both the pre- and post-tests. No rotation was required in extracting these factors. ${ }^{8}$ Whereas the second-order factor extracted during the pre-test obtained a Cronbach alpha coefficient of 0.93 and explained $60.787 \%$ of the variance in the first-order factors, the post-test second-order factor obtained a Cronbach alpha coefficient of 0.954 and explained $53.098 \%$ of the variance. The loadings of the first-order dimensions ranged between 0.454 and 0.888 , and between 0.537 and 0.907 in the pre- and post-test respectively.

\section{The relationship between ROR-change and meaning seeking}

Following the establishment of the CRI and PMP as valid and reliable measures of ROR-change and meaning seeking respectively, an investigation into the statistical relationship between these constructs was conducted by means of a canonical correlation analysis and $\mathrm{t}$-tests for independent samples. The former revealed a relationship $(R=0,59 ; p=0.05)$ between four of the CRI dimensions on the one hand, and four of the PMP dimensions on the other (see Table 3). This relationship explained $30.077 \%$ of the variance in the CRI and $32.26 \%$ of the variance in the PMP. The four PMP dimensions in the canonical correlation explain $10.737 \%$ of the variance in the CRI, whereas $12.258 \%$ of the variance in the PMP can be attributed to the four CRI dimensions therein.

The t-tests for independent samples indicated that the CRI group membership of participants - i.e. whether they scored

${ }^{4}$ Not all matched individuals invited attended the intervention.

${ }^{5}$ All participants were fully matched on a minimum of four criteria and partially on at least one adjacent criterion category (for example, if the individual was in the $18-25$ age category, the adjacent category was 26-30).

${ }^{6}$ Due to space limitations, all data are not provided. Interested parties can contact the primary author. ${ }^{7}$ This coefficient was found after omitting an item from the analysis of the self-acceptance dimension.

${ }^{8}$ This involved the omission of the fair treatment factor from the analysis due to low communalities, which suggests that fair treatment may not relate as strongly to individuals' search for meaning as is indicated in the literature. ${ }^{3}$ The rationale behind forming group 2 and 3 is a practical one: Given the direct and indirect costs of change management interventions for organisations, it stands to reason that employers would prefer to focus initiatives on individuals who display resistance to change (Group 3), rather than applying methods across the board. 
TABLE 3

CRI and PMP factors constituting the Canonical Correlation*

\begin{tabular}{llll}
\hline CRI & \multicolumn{2}{l}{ PMP } \\
\hline Factor & Weight & Factor & Weight \\
\hline Org culture supportive of change & 0.782379 & Fair treatment & 0.844597 \\
Job/task requirements & 0.753198 & Achievement & 0.604840 \\
Org structure & 0.745777 & Self-transcendence & 0.590531 \\
Change management practices & 0.627261 & Relationship & 0.588936
\end{tabular}

*Following advice from Eiselen (personal communication, 21 May 2007), interpretations were limited to factors where weights closely approximated or exceeded 0.6 .

TABLE 4

T-test for independent samples: The Impact of PMP Group Membership on CRI Scores

\begin{tabular}{llll}
\hline & \multicolumn{2}{l}{$\begin{array}{l}\text { CRI DIMENSION } \\
\text { SCORES }\end{array}$} & \\
\cline { 2 - 3 } CRI DIMENSION & $\begin{array}{l}\text { High PMP } \\
\text { scores }\end{array}$ & $\begin{array}{l}\text { Low PMP } \\
\text { scores }\end{array}$ & $\begin{array}{l}\text { SIGNIFICANCE } \\
\text { LEVEL OF } \\
\text { DIFFERENCE }\end{array}$ \\
\hline Change mission and strategy & 4.043 & 3.600 & $\mathbf{0 . 0 1 3}$ \\
External environment & 4.717 & 4.105 & $\mathbf{0 . 0 0 6}$ \\
Change leadership & 4.719 & 3.869 & $\mathbf{0 . 0 0 1}$ \\
Org culture supportive of change & 4.433 & 3.699 & $\mathbf{0 . 0 0 2}$ \\
Organisational structure & 6.192 & 5.423 & $\mathbf{0 . 0 0 0}$ \\
Change management practices & 4.196 & 3.434 & $\mathbf{0 . 0 0 0}$ \\
Change-related systems & 3.849 & 3.169 & $\mathbf{0 . 0 0 4}$ \\
Work unit climate & 3.554 & 3.230 & $\mathbf{0 . 0 7 2}$ \\
Job/task requirements & 4.666 & 3.977 & $\mathbf{0 . 0 0 0}$ \\
Motivation to change & 4.643 & 3.964 & $\mathbf{0 . 0 0 3}$ \\
Personal impact of change & 4.467 & 3.859 & $\mathbf{0 . 0 0 0}$ \\
Emotional impact of change & 4.044 & 3.544 & $\mathbf{0 . 0 0 5}$ \\
\hline
\end{tabular}

high or low - had a significant effect on their PMP scores. Conversely, participants' PMP group membership also had a significant effect on their CRI scores. The results of these t-tests are summarised in Tables 4 and 5.

Individuals in Group 2 scored consistently higher on the PMP than those in Group 3. Likewise, individuals in the high PMP group scored consistently higher on the CRI than their colleagues in the low PMP group. These results strongly suggest that the extent to which one experiences meaning in life will impact on whether one displays resistance to organisational change. ${ }^{9}$

\section{Inferential statistics}

Hypothesis 1 was tested by means of $\mathrm{t}$-tests for related samples. The results of this investigation indicated that the post-test scores of individuals who attended the Logo-OD intervention were higher than their pre-test scores on each of the $12 \mathrm{CRI}$ dimensions. ${ }^{10}$ However, as none of these differences were statistically significant, ${ }^{11}$ the null hypothesis could not be rejected. Although power coefficients ranging between 0.052 and 0.659 suggested a low probability of these results uncovering significant differences (Kerlinger \& Lee, 2000), the small effect sizes found (ranging between 0.011 and 0.23 ) also lent support to the null hypothesis. The results of these analyses are summarised in Table 6.

Hypothesis 2 was tested by means of t-tests for independent samples, the results of which are summarised in Table 7. The CRI mean scores of the experimental group were higher than those of the control group on eight of the 12 CRI dimensions
TABLE 5

T-test for independent samples: The Impact of CRI Group Membership on PMP

\begin{tabular}{llll}
\hline & \multicolumn{2}{l}{ PMP DIMENSION SCORES } & \\
\cline { 2 - 3 } & $\begin{array}{l}\text { Group 2 (high } \\
\text { CRI pre-test } \\
\text { scores) }\end{array}$ & $\begin{array}{l}\text { Group 3 (low } \\
\text { CRI pre-test } \\
\text { scores) }\end{array}$ & $\begin{array}{l}\text { SIGNIFICANCE } \\
\text { LEVEL OF } \\
\text { DIFFERENCE }\end{array}$ \\
\hline Achievement & 6.145 & 5.765 & $\mathbf{0 . 0 0 0}$ \\
Relationship & 6.064 & 5.603 & $\mathbf{0 . 0 0 0}$ \\
Religion & 6.150 & 5.594 & $\mathbf{0 . 0 0 0}$ \\
Self-transcendence & 5.891 & 5.353 & $\mathbf{0 . 0 0 0}$ \\
Self-acceptance & 5.836 & 5.609 & $\mathbf{0 . 0 4 6}$ \\
Intimacy & 6.094 & 5.761 & $\mathbf{0 . 0 1 8}$ \\
Fair treatment & 5.144 & 4.726 & $\mathbf{0 . 0 0 9}$ \\
\hline
\end{tabular}

after attending the Logo-OD intervention ${ }^{12}$ (refer to Group 1 results). However, neither of the applied inferential statistics revealed any statistically significant differences in this regard. As such, support was therefore provided for the null hypothesis. Despite the low observed power (between 0.05 and 0.19) suggesting a poor probability of discovering significant differences, the low effect sizes reported (between 0.006 and $0.166)$ largely supported the null hypothesis.

Finally, Hypothesis 3 was tested by means of a logistic regression analysis, which indicated that none of the biographical variables, and only the self-acceptance dimension of the PMP ( core $=14.49$, sig < 0.001 ) could predict whether an individual is likely to display resistance to or readiness for change.

\section{DISCUSSION}

The scales utilised in this study yielded satisfactory metric properties. Both the CRI and PMP were shown to be valid and reliable measures of the constructs they are reported to measure, particularly given the extraction of only one second-order factor in each instance, the high Cronbach alpha coefficients reported and the relatively high loadings of the theoretical dimensions (i.e. the primary factors) on the second-order factors (see Kerlinger \& Lee, 2000). This not only improves the accuracy with which the subsequent results can be interpreted, but also constitutes a methodological contribution of this study. Nevertheless, the implications of the omission of the fair treatment factor from the second-order factor analysis of the PMP should be considered, particularly with regard to its factor structure and relevance to the SA context.

As stated in the discussion of Figure 1 above, no evidence was found that Logo-OD, when applied in isolation, would bring about statistically significant changes in employee attitudes towards change. Nevertheless, the literature review provided substantiation for firstly the relationship that exists between one's experience of meaning and one's attitude towards organisational change, and secondly the potential role Logo-OD can play in facilitating organisational change. Whereas the relationship between meaning and ROR-change received substantial support from the empirical results, the consistent differences in mean scores on all 12 CRI dimensions in testing hypothesis 1 and eight of the 12 dimensions in testing hypothesis 2 provided some empirical evidence for the applicability of logotherapy as an OD intervention.

Gardner (2004) contends that changes in perceptions of phenomena (such as organisational change) "can be sudden,

\footnotetext{
'Conversely, these findings suggest that one's display of resistance to change/readiness for change may impact on the extent to which one finds meaning. However, in the context of this study - particularly given the findings from the literature review - the impact of one's experience of meaning on resistance to change enjoys precedence.

${ }^{10}$ Thise results apply to Grup 1. For Group 2, post-the

11The exception was a significant difference found between the pre- and post-test scores of Group 2 on the change leadership factor. However, the probability that this result is

"The exception was a significant difference found between the pre- and post-test score
}

attributable to chance - and therefore not a significant finding - cannot be rejected.
${ }^{12}$ These results apply to Groups 1 and 3 . For Group 2, experimental group means were higher on five of the dimensions. 
TABLE 6

Summary of Results of t-tests for related samples for hypothesis 1

\begin{tabular}{|c|c|c|c|c|c|c|c|c|c|c|c|c|}
\hline \multirow[b]{3}{*}{ CRI DIMENSION } & \multicolumn{4}{|c|}{ GROUP 1 (ALL PARTICIPANTS) } & \multicolumn{4}{|c|}{ GROUP 2 (HIGH CRI PRE-TEST SCORES) } & \multicolumn{4}{|c|}{ GROUP 3 (LOW CRI PRE-TEST SCORES) } \\
\hline & \multicolumn{2}{|c|}{ Means } & \multirow[b]{2}{*}{$\mathbf{t}$} & \multirow[b]{2}{*}{ sig } & \multicolumn{2}{|c|}{ Means } & \multirow[b]{2}{*}{$\mathbf{t}$} & \multirow[b]{2}{*}{ sig } & \multicolumn{2}{|c|}{ Means } & \multirow[b]{2}{*}{$\mathbf{t}$} & \multirow[b]{2}{*}{ sig } \\
\hline & Pre & Post & & & Pre & Post & & & Pre & Post & & \\
\hline Change mission and strategy & 3.776 & 4.029 & -1.516 & 0.146 & 3.262 & 3.467 & -0.939 & 0.370 & 3.262 & 3.467 & -1.145 & 0.285 \\
\hline External environment & 4.321 & 4.518 & 0.744 & 0.464 & 3.793 & 4.023 & 1.497 & 0.158 & 3.793 & 4.023 & -0.246 & 0.811 \\
\hline Change leadership & 4.257 & 4.307 & 0.904 & 0.375 & 3.457 & 3.669 & 2.258 & 0.042 & 3.457 & 3.669 & -1.326 & 0.212 \\
\hline Org culture supportive of change & 4.028 & 4.088 & 0.321 & 0.751 & 3.306 & 3.389 & 0.294 & 0.773 & 3.306 & 3.389 & 0.156 & 0.878 \\
\hline Organisational structure & 3.632 & 3.660 & -1.546 & 0.134 & 2.990 & 3.125 & -1.964 & 0.073 & 2.99 & 3.125 & -0.048 & 0.963 \\
\hline Change management practices & 3.760 & 3.801 & -0.735 & 0.469 & 3.085 & 3.204 & -0.049 & 0.961 & 3.085 & 3.204 & -1.312 & 0.214 \\
\hline Change-related systems & 3.514 & 3.562 & -1.081 & 0.289 & 2.739 & 2.894 & -0.587 & 0.567 & 2.739 & 2.894 & -1.061 & 0.308 \\
\hline Work unit climate & 3.464 & 3.580 & -1.381 & 0.182 & 3.032 & 3.044 & -1.451 & 0.181 & 3.032 & 3.044 & -0.631 & 0.541 \\
\hline Job/task requirements & 4.276 & 4.321 & -1.016 & 0.318 & 3.894 & 3.874 & -0.933 & 0.367 & 3.894 & 3.874 & -0.428 & 0.676 \\
\hline Motivation to change & 4.302 & 4.385 & 0.230 & 0.820 & 3.705 & 3.667 & 0.493 & 0.629 & 3.705 & 3.667 & -0.187 & 0.854 \\
\hline Personal impact of change & 4.138 & 4.170 & -0.654 & 0.518 & 3.872 & 3.729 & -1.623 & 0.125 & 3.873 & 3.729 & 1.304 & 0.215 \\
\hline Emotional impact of change & 3.833 & 3.858 & -1.320 & 0.198 & 3.297 & 3.396 & -1.002 & 0.335 & 3.298 & 3.396 & -0.836 & 0.418 \\
\hline
\end{tabular}

TABLE 7

Summary of Results of t-tests for independent samples for hypothesis $2^{*}$

\begin{tabular}{|c|c|c|c|c|c|c|c|c|c|c|c|c|}
\hline \multirow[b]{3}{*}{ CRI DIMENSION } & \multicolumn{4}{|c|}{ GROUP 1 (ALL PARTICIPANTS) } & \multicolumn{4}{|c|}{ GROUP 2 (HIGH CRI PRE-TEST SCORES) } & \multicolumn{4}{|c|}{ GROUP 3 (LOW CRI PRE-TEST SCORES) } \\
\hline & \multicolumn{2}{|c|}{ Means } & \multirow[b]{2}{*}{$\mathbf{t}$} & \multirow[b]{2}{*}{ sig } & \multicolumn{2}{|c|}{ Means } & \multirow[b]{2}{*}{$\mathbf{t}$} & \multirow[b]{2}{*}{ sig } & \multicolumn{2}{|c|}{ Means } & \multirow[b]{2}{*}{$\mathbf{t}$} & \multirow[b]{2}{*}{ sig } \\
\hline & Exp & Control & & & Exp & Control & & & Exp & Control & & \\
\hline Change mission and strategy & 4.084 & 4.008 & -0.267 & 0.790 & 4.559 & 4.722 & 0.476 & 0.638 & 3.562 & 3.423 & -0.414 & 0.682 \\
\hline External environment & 4.473 & 4.565 & 0.340 & 0.735 & 4.929 & 5.157 & 0.751 & 0.458 & 3.941 & 4.026 & 0.232 & 0.818 \\
\hline Change leadership & 4.247 & 4.352 & 0.373 & 0.711 & 4.708 & 5.153 & 1.313 & 0.199 & 3.786 & 3.697 & -0.266 & 0.792 \\
\hline $\begin{array}{l}\text { Org culture supportive of } \\
\text { change }\end{array}$ & 4.058 & 4.086 & 0.106 & 0.916 & 4.643 & 5.026 & 1.243 & 0.223 & 3.473 & 3.310 & -0.687 & 0.497 \\
\hline Organisational structure & 3.755 & 3.576 & -0.810 & 0.421 & 4.423 & 4.113 & -1.130 & 0.269 & 3.134 & 3.109 & -0.115 & 0.909 \\
\hline $\begin{array}{l}\text { Change management } \\
\text { practices }\end{array}$ & 3.891 & 3.740 & -0.615 & 0.541 & 4.373 & 4.482 & 0.377 & 0.708 & 3.333 & 3.105 & -0.901 & 0.374 \\
\hline Change-related systems & 3.600 & 3.527 & -0.270 & 0.788 & 4.300 & 4.171 & -0.349 & 0.730 & 2.900 & 2.939 & 0.156 & 0.877 \\
\hline Work unit climate & 3.614 & 3.561 & -0.197 & 0.845 & 4.063 & 4.214 & 0.439 & 0.664 & 3.240 & 2.875 & -1.320 & 0.197 \\
\hline Job/task requirements & 4.423 & 4.245 & -1.050 & 0.299 & 4.818 & 4.755 & -0.297 & 0.768 & 4.000 & 3.802 & -1.260 & 0.217 \\
\hline Motivation to change & 4.317 & 4.434 & 0.430 & 0.669 & 4.948 & 5.183 & 0.843 & 0.405 & 3.595 & 3.720 & 0.373 & 0.712 \\
\hline Personal impact of change & 4.329 & 4.052 & -1.440 & 0.154 & 4.804 & 4.479 & -1.550 & 0.131 & 3.786 & 3.696 & -0.361 & 0.720 \\
\hline Emotional impact of change & 3.897 & 3.824 & -0.377 & 0.707 & 4.413 & 4.306 & -0.464 & 0.646 & 3.381 & 3.406 & 0.120 & 0.905 \\
\hline
\end{tabular}

*All significance levels cited are two-tailed and take cognisance of whether equality of variance was assumed.

dramatic, and permanent" (p. 60), or attributed to gradual decisions that take place "over a longer period of time" (p. 4). However, the former are rarely sustainable, and individuals are likely "to slip back to earlier ways of thinking" (p. 211). In the context of this study, where a focus on changing individuals' perceptions relates directly to them finding meaning, a study by Seligman, Steen, Park and Peterson (2005) largely confirms this proposition. These authors conducted research into whether individuals' experience of 'happiness' - one component of which is meaning - could be increased by means of a direct intervention. Of significance is that the possibility was considered that "there would be no exercises that would make people lastingly happier" - particularly given findings that "people adapt rapidly to positive changes in their world and soon return to baseline levels of happiness" (Seligman et al., 2005, p. 414).

The results of these authors' study indicate that the applied interventions did bring about a change in the extent to which individuals experienced happiness. However, such changes were not permanent. In explaining these findings, Seligman et al. (2005) cite research indicating that it "may be that the mere act of doing something assigned by a professional in the expectation of gain in the form of a boost in happiness is sufficient to lift one's spirits in the short term" (p. 419; emphasis added). However, what these authors found was that "the long-term effects of the [interventions] were most pronounced for those who continued the exercises on their own" (p. 419). Therefore, those individuals who had repeated exposure to the interventions were most likely to experience sustainable increases in their happiness levels.

The above postulations have significant implications for the interpretation of the results of this study. Whereas Gardner's (2004) proposition suggests that few employees will adapt to the shifts in perceptions required for effective organisational change in a short space of time, Seligman et al.'s (2005) findings imply that although one's experience of meaning can be influenced by means of a single intervention, such changes may not be sustainable over the long term. Moreover, Wrzesniewski (2003) also indicates that finding meaning in work is about more than one's attitude towards work - internal and external factors also play a significant role..$^{13}$

Therefore, as emphasised earlier, a single and isolated application of Logo-OD may not be sufficient to help individuals find meaning to the extent that resistance to change is significantly reduced. Rather, a "myriad of follow-up interventions" (Avolio \& Luthans, in Puente et al., 2007, p. 17) may be required to bring about readiness for change. In the model presented in Figure 1 it was indicated that such "follow-up interventions" should relate to firstly creating a positive organisational context, and 


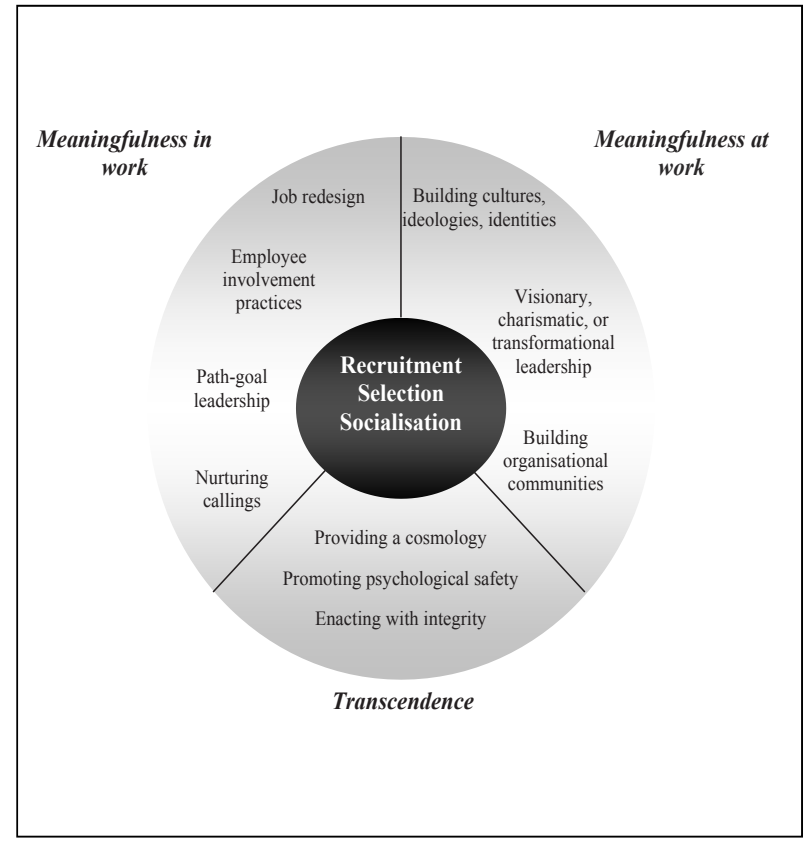

FIGURE 3

Organisational practices that foster meaningfulness (adapted from Pratt \& Ashforth, 2003, p. 316)

secondly to appropriately framing organisational change. Whereas the former may be greatly facilitated through the application of models presented by authors such as Pratt and Ashforth (2003, see Figure 3) ${ }_{1}^{14}$ the framing of changes should be informed by concepts central to Logo-OD (see Table 8 ). The latter is particularly important as "framing plays a major role in change responses", to the extent that it affects "acceptance of, or resistance to change" (Chreim, 2006, p. 316, 317).

\section{Practical implications of the study}

Organisations need to take cognisance of the importance of meaning in the lives of employees and - given its relationship with ROR-change - the continued survival of the organisation. Therefore, efforts should be made to diagnose and address a potential lack of meaning - or an 'existential vacuum' - in the organisation. With regard to the latter, it was shown that organisations undergoing change may benefit from the novel approach of Logo-OD. The use of an instrument such as the PMP to identify individuals who are potentially experiencing 'existential frustration', and may therefore be more prone to display resistance to change, may then also be more cost-effective than implementing Logo-OD throughout the organisation. ${ }^{15}$

In addition, instruments such as the CRI have great value in identifying potential epicentres of resistance to change in organisations. Based on such information, the Logo-OD intervention may be customised to meet the needs of the organisation, in order to ensure that it fulfils its objective of serving as a positive trigger for organisational change.

\section{Limitations of the study}

The limitations of the study were identified as follows:

- The size of the sample precluded the application of firstorder factor analysis on the PMP and CRI, and constrained the power of the study to reject false null hypotheses.

- The internal validity of the study was limited by the use of a quasi-experimental design and the subsequent lack of equivalence between the experimental and control groups.
TABLE 8

Framing Based on the Principles underlying Logo-OD

\begin{tabular}{|c|c|}
\hline PRINCIPLE & APPLICATION IN FRAMING \\
\hline The will to meaning & $\begin{array}{l}\text { As the will to meaning is the primary motivation in } \\
\text { human existence, organisational change initiatives } \\
\text { should be framed in such a way that these are } \\
\text { viewed as potentially contributing to one's search } \\
\text { for meaning. This will intrinsically motivate } \\
\text { individuals to support such changes through } \\
\text { readiness for change behaviours. }\end{array}$ \\
\hline Values & $\begin{array}{l}\text { Individuals should perceive change initiatives } \\
\text { as potentially contributing to the expression } \\
\text { of creativity and innovation in their jobs } \\
\text { (creative values), to them experiencing fulfilling } \\
\text { relationships and a sense of community } \\
\text { (experiential values). Although the reliance } \\
\text { on attitudinal values to promote individual } \\
\text { change while the organisation does not address } \\
\text { unfavourable circumstances constitutes } \\
\text { exploitation, these values may be crucial when } \\
\text { severe strain is placed on employees' coping } \\
\text { resources, and creative and experiential values } \\
\text { are undermined. }\end{array}$ \\
\hline Self-transcendence & $\begin{array}{l}\text { Individuals may - given the right circumstances } \\
\text { - not only place the goals of the organisation } \\
\text { before their own, but also find meaning in them. } \\
\text { Such circumstances may include viewing the } \\
\text { changes as potentially resulting in contributing } \\
\text { to the needs of others, or society (Kets de Vries, } \\
\text { 2001; Milliman, Ferguson, Trickett \& Condemi, } \\
\text { 1999). Transformational leadership and an } \\
\text { inspiring vision or organisational values may play } \\
\text { a crucial role here (Burger \& Crous, 2002). }\end{array}$ \\
\hline Noö-dynamics* & $\begin{array}{l}\text { Consistent with Lewin's (1951) change model, } \\
\text { framing will motivate individuals if it clearly } \\
\text { indicates that past successes (the meaning that } \\
\text { has been found) are insufficient for sustained } \\
\text { performance, and that organisational change } \\
\text { is required to ensure that potential future } \\
\text { achievements (the meaning to be fulfilled) are } \\
\text { realised. }\end{array}$ \\
\hline The existential vacuum & $\begin{array}{l}\text { Employees "generally do not support change } \\
\text { unless compelling reasons convince them to do } \\
\text { so... People's readiness for change depends } \\
\text { on creating a felt need for change" (Cummings } \\
\& \text { Worley, 2001, p.156). Using framing to depict } \\
\text { the outcomes of not changing may communicate } \\
\text { such a need for change - e.g. depicting the } \\
\text { (unchanged) organisation as one that is failing, } \\
\text { and hence unable to provide employees with } \\
\text { a sense of sustained identity, community, and } \\
\text { ultimately, meaning. }\end{array}$ \\
\hline
\end{tabular}

"Noö-dynamics involves a healthy tension between what one "is and what one should become" (Frankl, 1984, p. 127) and is critical in fulfilling the will to meaning.

- The external validity of the study was constrained by the sample used. Only one organisation - an ICT company in the private sector - constituted the target population, which inhibits the extent to which the findings can be generalised to other organisations, industries and sectors.

- The scope of the study precluded an empirical investigation into the additional components (creating a positive organisational context, as well as framing based on the principles underlying logotherapy) of the model presented in Figure 1.

- Efforts to enhance the generalisability of Logo-OD resulted in this intervention being designed to accommodate change as a generic concept, rather than focusing on specific change initiatives being undertaken. This may have limited the value that individuals obtained from attending the Logo-OD workshop which, in turn, may have had an impact on the results obtained.

Despite these limitations, the objectives of this study were achieved. The relationship between the constructs of RORchange and meaning seeking was shown empirically, and some

${ }^{14}$ In this model, a distinction is made between meaning in work (the role that one performs - or "in what one does") and meaning at work (one's sense of belonging: "Finding meaning in whom one surrounds oneself with as part of organisational membership, and/or in the goals, values, and beliefs that the organisation espouses" (Pratt \& Ashforth, 2003, p. 314).

${ }^{15}$ Despite this, it may be argued that all employees may benefit from attending such an intervention, regardless of their PMP profile. 
evidence was found of the impact of Logo-OD on ROR-change. Thus it was shown that logotherapy is applicable as an OD intervention in the context of organisational change.

\section{Future research opportunities}

Following the outcomes and limitations of the research discussed above, the following recommendations for further research are presented:

- The Logo-OD intervention should be customised to pertain to a specific change initiative, rather than treating change as a theoretical concept. Research should therefore be conducted to ascertain whether such a contextualisation of the intervention yields more significant results than the more generalised approach taken in this study.

- As the finding of meaning and the changing of individual attitudes require a longer-term approach involving multiple (follow-up) interventions, longitudinal research may yield more useful results in determining the impact of meaning-centred interventions than the cross-sectional design utilised in this study.

- The development of instruments to investigate the meaning found in work, in particular, rather than taking a more general approach such as the PMP, may increase the value organisation's gain from utilising such diagnostics in addressing resistance to change.

- Value may be gained from an investigation into the impact of demographic characteristics, as well as one's attitude (i.e. resistance vs. readiness) to change on meaning seeking.

- Further research is required to verify the impact of the additional components of the model represented in Figure 1 on the experience of meaning in the organisational change context.

\section{Value of the study}

Despite the flourishing of research pertaining to organisational change since the 1980s, and more than 60 years' worth of evidence from research and practice relating to the fields of OD and logotherapy, virtually no research was found that relates directly to the problem statement of this study. Therefore, the fundamental value that was added by this study was embodied in its efforts to address this evident gap in the research.

In addition, this study also served to expand on the three domains of knowledge investigated by indicating firstly a novel application of logotherapy, and secondly a novel approach to organisational change and development. Finally, as far as could be ascertained, this study represented the first application of the PMP in the SA context, which therefore provided valuable knowledge regarding its local applicability and utility. Overall, this study may have made a valuable contribution to understanding and addressing the phenomenon of resistance to change in organisations in this country.

\section{Conclusion}

Resistance to change often emerges due to the threat that organisationalchangerepresents tomany employees' experience of meaning in their work contexts. In such cases, organisations may draw from the theory and practice of logotherapy to assist employees in their search for meaning, thereby increasing the likelihood of them displaying readiness for change. Therefore, the evidence supported the applicability of logotherapy as an OD intervention.

However, given the complexity of organisational change, the difficulty inherent in changing employees' attitudes towards it, and the unlikelihood of a single intervention bringing about a significant change in individuals' experience of meaning, LogoOD is not proposed to be a panacea in addressing resistance to change. Rather, it is positioned as a positive trigger event for organisational change. For optimal effectiveness, LogoOD must be accompanied by interventions to create a positive organisational context, as well as efforts to frame change initiatives based on the principles underlying logotherapy. Such a focus on the individual's primary motivation in life - finding meaning - will ultimately play a significant role in organisations achieving a people-based competitive advantage.

\section{REFERENCES}

Antonacopoulou, E.P. \& Gabriel, Y. (2001). Emotion, learning and organizational change: towards an integration of psychoanalytic and other perspectives. Journal of Organizational Change Management, 14(5), 435-451.

Ambrose, D. (1996). Healing the downsized organization. New York: Harmony.

Argyris, C. (1964). T-groups for organizational effectiveness. Harvard Business Review, 2, 68-70.

Armenakis, A.A., Harris, S.G. \& Mossholder, K.W. (1993). Creating readiness for organizational change. Human Relations, 46(6), 681-703.

Atkinson, P. (2005). Managing resistance to change. Management Services, 49(1), 14-19.

Avolio, B.J. \& Luthans, F. (2006). The high impact leader: Moments matter in accelerating authentic leadership development. New York: McGraw-Hill.

Barney, J. (1995). Looking inside for competitive advantage. Academy of Management Executive, 9, 49-81.

Bartlett, C.A. \& Ghoshal, S. (1994). Changing the role of top management: Beyond strategy to purpose. Harvard Business Review, 72(6), 79-88.

Bashford, S. (2004). The survivor syndrome. London: Haymarket Business Publications.

Beckhard, R. (1994). What is organization development? In W.L. French, C.H. Bell, Jr. \& R.A. Zawacki (Eds.). Organization development and transformation: Managing effective change (4th Ed.). Boston: Irwin McGraw-Hill, pp. 21-24.

Bennett, H. \& Durkin, M. (2000). The effects of organisational change on employee psychological attachment: An exploratory study. Journal of Managerial Psychology, 15(2), 126-147.

Berrisford, S. (2005). Using Appreciative Inquiry to drive change at the BBC. Strategic Communication Management, 9(3), 22-25.

Bovey, W.H. \& Hede, A. (2001). Resistance to organizational change: The role of defence mechanisms. Journal of Managerial Psychology, 16(7), 534-548.

Burger, D.H. \& Crous, F. (2002). An existential/humanistic perspective on strategy. Paper presented at the 8th Annual Psychological Society of South Africa (PsySSA) Conference, Cape Town.

Burnes, B. (2003). Managing change and changing managers from ABC to XYZ. Journal of Management Development, 22(7), 627-642.

Burnes, B. (2004). Emergent change and planned change - competitors or allies? The case of XYZ construction. International Journal of Operations $\mathcal{E}$ Production Management, 24(9), 886-902.

Campbell, D.T. \& Stanley, J.C. (1963). Experimental and quasiexperimental designs for research. Boston: Houghton Mifflin.

Carbery, R. \& Garavan, T.N. (2005). Organisational restructuring and downsizing: Issues related to learning, training and employability of survivors. Journal of European Industrial Training, 29(6), 488-508.

Carnall, C.A. (2003). Managing change in organizations (4th Ed.). Harlow: FT/Prentice Hall.

Cartwright, S. \& Cooper, G.L. (1994). The human effects of mergers and acquisitions. In G.L. Cooper \& D.M. Rousseau (Eds.). Trends in organizational behaviour, volume 1. New York: Wiley, pp. 47-61.

Cartwright, S. \& Cooper, G.L. (1995). Organizational marriage: "hard" versus "soft" issues? Personnel Review, 24(3), 32-42.

Cascio, W.F. (1995). Whither industrial and organizational psychology in the changing world of work? American Psychologist, 50(11), 928-939. 
Cascio, W.F. (1998). Applied psychology in human resource management (5th Ed.). Upper Saddle River: Prentice Hall

Caudron, S. (1997). The search for meaning at work. Training and Development, 51(9), 24-27.

Chapman, J.A. (2002). A framework for transformational change in organisations. Leadership and Organization Development Journal, 23(1), 16-25.

Chawla, A. \& Kelloway, E.K. (2004). Predicting openness and commitment to change. Leadership $\mathcal{E}$ Organization Development Journal, 25(6), 485-498.

Chreim, S. (2006). Postscript to change: Survivors' retrospective views of organizational changes. Personnel Review, 35(3), 315-335.

Cook, J. \& Crossman, A. (2004). Satisfaction with performance appraisal systems: A study of role perceptions. Journal of Managerial Psychology, 19(5), 526-541.

Counsell, R., Tennant, C. \& Neailey, K. (2005). The development of a model to support synchronous change. Measuring Business Excellence, 9(3), 13-20.

Cummings, T.G. \& Worley, C.G. (2001). Organization development and change (7th Ed.). Cincinnati: South-Western College.

Das, A.K. (1998). Frankl and the realm of meaning. Journal of Humanistic Counseling Education and Development, 36(4), 199212.

De Cuyper, N. \& De Witte, H. (2005). Job insecurity: Mediator or moderator of the relationship between type of contract and various outcomes? South African Journal of Industrial Psychology, 31(4), 79-86.

De Greene, K.B. (1982). The adaptive organization: Anticipation and management of crisis. New York: John Wiley.

Doherty, N. \& Horsted, J. (1995). Helping survivors stay on board. People Management, 1(1), 26-31.

Drucker, P.F. (2002). They're not employees, they're people. Harvard Business Review, 80(2), 70-77.

Elving, W.J.L.(2005). The role of communication in organisational change. Corporate Communications: An International Journal, 10(2), 129-138.

Fabry, J.B. (1987). The pursuit of meaning: Viktor Frankl, logotherapy and life (revised Ed.). Berkeley: Institute of Logotherapy Press.

Fabry, J.B. (1988). Guideposts to meaning: Discovering what really matters. Berkeley: Institute of Logotherapy Press.

Fiorito, J., Bozeman, D.P., Young, A. \& Meurs, J.A. (2007). Organizational commitment, human resource practices, and organizational characteristics. Journal of Managerial Issues, 19(2), 186-207.

Folger, R. \& Skarlicki, D.P. (1999). Unfairness and resistance to change: Hardship as mistreatment. Journal of Organizational Change Management, 12 (1), 35-50.

Frances, M. (1995). Organizational change and personal mythology. Personnel Review, 24(4), 58-68.

Frankl, V.E. (1967). Psychotherapy and existentialism: Selected papers on logotherapy. New York: Washington Square Press.

Frankl, V.E. (1969). The will to meaning: Foundations and applications of logotherapy. London: Souvenir Press.

Frankl, V.E. (1978). The unheard cry for meaning: Psychotherapy and humanism. New York: Washington Square Press.

Frankl, V.E. (1984). Man's search for meaning (revised Ed.). New York: Washington Square Press.

Frankl, V.E. (1986). The doctor and the soul: From psychotherapy to logotherapy (3rd Ed.). New York: Random House.

Frankl, V.E. (1988). The will to meaning: Foundations and applications of logotherapy (2nd Ed.). New York: Meridian.

Frankl, V.E. (1990). Facing the transitoriness of human existence. Generations, 14(4), 7-11.

Frankl, V.E. (1992). Meaning in industrial society. The International Forum for Logotherapy, 15, 66-70.

Frankl, V.E. (2000a). Man's search for ultimate meaning. Cambridge, MA: Perseus.

Frankl, V.E. (2000b). Recollections: An autobiography (translated from German by J. Fabry \& J. Fabry). Cambridge, MA Perseus.
French, W.L. \& Bell, C.H., Jr. (1990). Organization development: Behavioral science interventions for organization improvement (4th Ed). Upper Saddle River: Prentice Hall.

French, W.L. \& Bell, C.H., Jr. (1999). Organization development: Behavioral science interventions for organization improvement (6th Ed.). Upper Saddle River: Prentice Hall.

Gardner, H. (2004). Changing minds: The art and science of changing our own and other people's minds. Boston: Harvard Business School Press.

Ghoshal, S. \& Bartlett, C.A. (1996). Rebuilding behavioral context: A blueprint for corporate renewal.Sloan Management Review, 37(2), 23-36.

Gratton, L. (1998). The new rules of HR strategy. HR Focus, 75(6), 13-14.

Gratton, L. (2000). Living strategy: Putting people at the heart of corporate business. London: Prentice Hall.

Greenhaus, J.H., Callanan, G.A. \& Godshalk, V.M. (2000). Career management (3rd Ed.). Fort Worth: Harcourt Brace.

Greenstein, M. \& Breitbart, W. (2000). Cancer and the experience of meaning: A group psychotherapy for people with cancer. American Journal of Psychotherapy, 54(4), 486-500.

Hacker, M. \& Washington, M. (2004). How do we measure the implementation of large-scale change? Measuring Business Excellence, 8(3), 52-59.

Hammer, M. (1996). Beyond reengineering. London: Harper Collins Business.

Hammer, M. \& Champy, J. (1993). Reengineering the corporation: A manifesto for business revolution. London: Nicholas Brealy.

Havenga, A.A. \& Coetzer, P. (1997). Viktor Frankl the man. In F. Crous, A.A. Havenga, P. Coetzer \& G. van den Heever (Eds.). On the way to meaning: Essays in remembrance of Viktor Frankl . Benmore: Viktor Frankl Foundation of South Africa, pp. 11-19.

Heil, G., Bennis, W. \& Stephens, D.C. (2000). Douglas McGregor, revisited: Managing the human side of the enterprise. New York: John Wiley.

Hellgren, J., Näswall, K. \& Sverke, M. (2005). There's more to the picture than meets the eye: A comparison of downsizing survivors with changed and unchanged content. South African Journal of Industrial Psychology, 31(4), 87-93.

Higgs, M. (2003). How can we make sense of leadership in the 21st century? Leadership \& Organization Development Journal, 24(5), 273-284

Huysamen, G.K. (1993). Metodologie vir die sosiale en gedragswetenskappe. Johannesburg: International Thompson.

Jackson, S.E. \& Schuler, R.S. (1999). Understanding human resource management in the context of organizations and their environments. In R.S. Schuler \& S.E. Jackson (Eds.) Strategic human resource management. Malden: Blackwell, pp. $4-28$.

Johnson, D.M. (2004). Adaptation of organizational change models to the implementation of quality standard requirements. International Journal of Quality $\mathcal{E}$ Reliability Management, 21(2), 154-174

Karp, T. (2004). Learning the steps of the dance of change: Improving change capabilities by integrating futures studies and positive organisational scholarship. Foresight, 6(6), 349-355.

Kausch, K.D. \& Amer, K. (2007). Self-transcendence and depression among Aids memorial quilt panel makers. Journal of Psychosocial Nursing, 45(6), 45-53.

Kerlinger, F.N. \& Lee, H.B. (2000). Foundations of behavioral research (4th Ed.). Fort Worth: Harcourt Brace.

Kets de Vries, M.F.R. (2001). The leadership mystique: A user's manual for the human enterprise. London: Prentice Hall.

Kinnear, C. \& Roodt, G. (1998). The development of an instrument to measure organisational inertia. South African Journal of Industrial Psychology, 24(2), 44-54.

Lawrence, P.R. (1970). How to deal with resistance to change. In G.W. Dalton, P.R. Lawrence \& L.E. Greiner (Eds.) Organizational change and development. Homewood, IL: Irwin, pp. 181-197. 
Lewin, K. (1951). Field theory in social science. New York: Harper \& Row.

Ludema, J.D., Cooperrider, D.L. \& Barrett, F.J. (2001). Appreciative inquiry: The power of the unconditional positive question. In P. Reason \& H. Bradbury (Eds.). Handbook of action research. London: Sage, pp. 189-199.

Luthans, F. \& Avolio, B. (2003). Authentic leadership development. In K.S. Cameron, J.E. Dutton \& R.E. Quinn (Eds.). Positive organizational scholarship: Foundations of a new discipline. San Francisco: Berret Koehler, pp. 241 - 258.

Markow, F. \& Klenke, K. (2005). The effects of personal meaning and calling on organizational commitment: An empirical investigation of spiritual leadership. The International Journal of Organizational Analysis, 13(1), 8-27.

McGreevy, M. (2003a). Managing the transition. Industrial and Commercial Training, 35(6), 241-246.

McGreevy, M. (2003b). The changing nature of work. Industrial and Commercial Training, 35(5), 191-195.

McGregor, D. (1960). The human side of enterprise. New York: McGraw-Hill.

Milliman, J., Ferguson, J., Trickett, D. \& Condemi, B. (1999). Spirit and community at Southwest Airlines: An investigation of a spiritual values-based model. Journal of Organizational Change Management, 12(3), 221-233.

Mirvis, P.H. (1990). Organization development: Part 2 - a revolutionary perspective. Research in Organizational Change and Development, 4, 1-66.

Moomal, Z. (1999). The relationship between meaning in life and mental well-being. South African Journal of Psychology, 29(1), 42-48.

Morin, E.M. (1995). Organizational effectiveness and the meaning of work. In T.C. Pauchant \& Associates (Eds.). In search of meaning: Managing for the health of our organizations, our communities, and the natural world. San Francisco: JosseyBass, pp. 29-64.

Morin, W.J. (1994). HR as director of people strategy. $H R$ Magazine, 39(12), 52-54.

Mullins, L.J. (1999). Management and organisational behaviour (5th Ed.). London: Pitman.

Newstrom, J.W. \& Davis, K. (1997). Organizational behavior: Human behavior at work (10th Ed.). New York: McGraw-Hill.

Nguyen-Huy, Q. (2000). Do humanistic values matter? Academy of Management Proceedings. Retrieved June 20, 2002, from the World Wide Web: http://search.epnet.com

Nijhof, W.J., De Jong, M.J. \& Beukhof, G. (1998). Employee commitment in changing organizations: An exploration. Journal of European Industrial Training, 22(6), 243-248.

O'Reilly, C.A. \& Pfeffer, J. (2000). Hidden value: How great companies achieve extraordinary results with ordinary people. Boston: Harvard Business School Press.

Piderit, S.K. (2000). Rethinking resistance and recognizing ambivalence: A multidimensional view of attitudes towards an organizational change. Academy of Management Review, 25(4), 783-794.

Porras, J.I. \& Robertson, P.J. (1992). Organizational development: Theory, practice, and research. In M.D. Dunnette \& L.M. Hough (Eds.). Handbook of Industrial and Organizational Psychology (2nd Ed.). Palo Alto: Consulting Psychologists Press, pp. 719-822.

Prahalad, C.K. \& Hamel, G. (1990). The core competencies of the corporation. Harvard Business Review, 68, 79-91.

Pratt, A. \& Ashforth, B.E. (2003). Fostering meaningfulness in working and at work. In K.S. Cameron, J.E. Dutton \& R.E. Quinn (Eds.). Positive organizational scholarship: Foundations of a new discipline. San Francisco: Barrett Koehler, pp. 309-327.

Proctor, T. \& Doukakis, I. (2003). Change management: The role of internal communication and employee development. Corporate Communications: An International Journal, 8(4), 268-277.

Puente, S., Crous, F. \& Venter, A. (2007). The role of a positive trigger event in actioning authentic leadership development. SA Journal of Human Resource Management, 5(1), 11-18.
Richardson, H.A. \& Vandenberg, R.J. (2005). Integrating managerial perceptions and transformational leadership into a work-unit level model of employee involvement. Journal of Organizational Behavior, 26, 561-589.

Robbins, S.P. (1990). Organization theory: Structure, design and applications (3rd Ed.). Englewood Cliffs: Prentice Hall.

Robbins, S.P., Odendaal, A. \& Roodt, G. (2003). Organisational behaviour: Global and Southern African perspectives. Cape Town: Pearson Education.

Roodt, G., Kinnear, C. \& Erwee, R. (2003). Organisational inertia: Contrasting results in Australia and South Africa. South African Journal of Industrial Psychology, 29(2), 1-5.

Roodt, G., Kinnear, C., Erwee, R., Smith, D., Lynch, B. \& Millet, B. (2001). Measurement of organisationalinertia:Portability of a South African scale in the Australian context. South African Journal of Industrial Psychology, 27(2), 57-61.

Rosnow, R.L. \& Rosenthal, R. (1996). Beginning behavioral research: A conceptual primer (2nd Ed.). Englewood Cliffs: Prentice Hall.

Rossouw, G.J. (2002). Business ethics in Africa. Cape Town: Oxford Southern Africa.

Schein, E.H. (1994). Organizational psychology (3rd Ed.). Upper Saddle River: Prentice Hall.

Schein, E.H. (1995). Process consultation, action research and clinical enquiry: Are they the same? Journal of Managerial Psychology, 10(6), 14-19.

Schlechter, A.F. \& Engelbrecht, A.S. (2006). The relationship between transformational leadership, meaning and organizational citizenship behaviour. Management Dynamics, 15(4), 2-16.

Schuler, R.S. \& Jackson, S.E. (Eds.) (1999). Strategic human resource management. Oxford: Blackwell Business.

Schuler, R.S., Jackson, S.E. \& Storey, J. (2001). HRM and its link with strategic management. In J. Storey (Ed.). Human resource management: A critical text (2nd Ed.). London: International Thompson Learning, pp. 114-130.

Seligman, M.E.P., Steen, T.A., Park, N. \& Peterson, C. (2005). Positive psychology progress: Empirical validation of interventions. American Psychologist, 60(5), 410-421.

Shantall, T. (1989). Viktor Frankl's existential theory. In W.F. Meyer, C. Moore \& H.G. Viljoen (Eds.). Personality theories - from Freud to Frankl. Johannesburg: Lexicon, pp. 421-439.

Shimmin, S. \& Van Strien, P.J. (1998). History of the psychology of work and organization. In J.D. Drenth, H. Thierry \& C. de Wolff (Eds.). Handbook of work and organizational psychology volume 1 (2nd Ed.). East Sussex: The Psychology Press, pp. 71-99.

Smith, I. (2005a). Achieving readiness for organisational change. Library Management, 26(6/7), 408-412.

Smith, I. (2005b). Continuing professional development and workplace learning 11: Managing the "people" side of organisational change. Library Management, 26(3), 152-155.

Southwick, S.M., Gilmartin, R., McDonough, P. \& Morrissey, P. (2006). Logotherapy as an adjunctive treatment for chronic combat-related PTSD: A meaning-based intervention. American Journal of Psychotherapy, 60(2), 161-174.

Trader-Leigh, K.E. (2002). Case study: Identifying resistance in managing change. Journal of Organizational Change Management, 15(2), 138-155.

Ugboro, I.O. (2006). Organizational commitment, job redesign, employee empowerment and intent to quit among survivors of restructuring and downsizing. Journal of Behavioral and Applied Management, 7(3), 232-257.

Vakola, M. \& Nikolaou, I. (2005). Attitudes towards organizational change: What is the role of employees' stress and commitment? Employee Relations, 27(2), 160-174.

Vakola, M., Tsaousis, I. \& Nikolaou, I. (2004). The role of emotional intelligence and personality variables on attitudes toward organisational change. Journal of Managerial Psychology, 19(2), 88-110.

Wanberg, C.R. \& Banas, J.T. (2000). Predictors and outcomes of openness to changes in a reorganizing workplace. Journal of Applied Psychology, 85(1), 132-142. 
Washburn, E.R. (1998). The physician leader as logotherapist. Physician Executive, 24(4), 34-39.

Watkins, J.M. \& Mohr, B.J. (2001). Appreciative inquiry: Change at the speed of imagination. San Francisco: Jossey-Bass/Pfeiffer.

Watson, G.W. (2003). Ideology and the symbolic construction of fairness in organizational change. Journal of Organizational Change Management, 16(2), 154-168.

Weber, P.S. \& Weber, J.E. (2001). Changes in employee perceptions during organizational change. Leadership and Organization Development Journal, 22(6), 291-300.

Wong, P.T.P. (1997). Charting the course of research on meaning seeking. Paper presented at the Roundtable on Meaning Research in the World Congress of Logotherapy, Dallas. Retrieved July 10, 2001, from the World Wide Web: http:// www.twu.ca/cpsy/faculty/wong/wong.htm

Wong, P.T.P. (1998). Implicit theories of personal life and the development of the Personal Meaning Profile. In P.T.P. Wong
\& P.S. Fry (Eds.). The human quest for meaning: A handbook of psychological research and clinical applications. Mahwah: Lawrence Erlbaum Associates, pp. 111-140.

Worrall, L. \& Cooper, C. (2004). Managers, hierarchies and perceptions: A study of UK managers. Journal of Managerial Psychology, 19(1), 41-68.

Wrzesniewski, A. (2003). Finding positive meaning in work. In K.S. Cameron, J.E. Dutton \& R.E. Quinn (Eds.). Positive organizational scholarship: Foundations of a new discipline. San Francisco: Barrett Koehler, pp. 296-308.

Xavier, S. (2005). Are you at the top of your game? Checklist for effective leaders. Journal of Business Strategy, 26(3), 35-42.

Young, A.P. (2000). "I'm just me": A case study of managerial resistance. Journal of Organizational Change Management, 13(4), 375-388 